\title{
Economics of Using Cotton Gin Trash as a Supplemental Feed for Range Cattle
}

\author{
KENNETH B. YOUNG AND MESBAH U. AHMED
}

\begin{abstract}
The economic use of alternative supplemental feeds was evaluated for a 2,024-ha cow-calf ranch operation in the Texas Rolling Plains. Particular interest was focused on the use of gin trash as a supplemental feed. The estimated value of gin trash compared with alternative supplemental feeds ranged up to $\$ 23.75$ per ton. Potential ranch carrying capacity and annual net income were expanded with a supplemental feeding program including gin trash.
\end{abstract}

Returns to rangeland resources may be increased by supplemental feeding. Supplemental feeding programs may be used to expand carrying capacity, improve performance on rangeland, and relieve grazing pressure when range conditions are poor.

On the Texas Rolling Plains, typical supplemental feeds used are range cubes, protein blocks, cottonseed meal, and alfalfa hay or other roughage during winter months. Ranges in this region are dominated by warm-season species that usually furnish adequate amounts of quality forage from April to November. In the remaining dormant months, however, the range tends to be deficient in protein, phosphorus, vitamin $\mathrm{A}$, and sometimes energy, particularly with heavy stocking rates.

Cotton gin trash is a relatively cheap and abundant by-product available from gins in the Southern High Plains of Texas. Gin trash is used currently in commercial feedlot rations in the Texas-Oklahoma Panhandle as a substitute for traditional roughages and is available in bulk form directly from gins or in pellet form from processors.

The major purpose of this paper was to evaluate the economic use of alternative supplemental feeds on a cow-calf ranch in the Texas Rolling Plains, with particular reference to use of gin trash as a supplemental feed.

\section{Methodology}

\section{Nutritive Value of Gin Trash}

Basic nutritive values of supplemental feed ingredients including cotton burrs, the principal component of gin waste, have been determined by the National Academy of Sciences (1970). A laboratory analysis of Hi Pro Feeds of Friona, Texas, indicates that $0.45 \mathrm{~kg}$ of representative ground gin trash in this region contains 0.46 megacalories net energy for maintenance (mcal NEM), 0.15 mcal net energy for gain (mcal NEG), $.19 \mathrm{~kg}$ total digestible nutrients (TDN), $.037 \mathrm{~kg}$ crude protein (CP), $.014 \mathrm{~kg}$ digestible protein (DP), and .009

The authors are assistant professor, Department of Agricultural Economics. Texas Tech University, Lubbock 79409; and assistant professor, Department of Business Administration, Eastern Kentucky University, Richmond, Kentucky 40475. Ahmed was formerly graduate research assistant, Department of Agricultural Economics, Texas Tech University.

Manuscript received March 6, 1978 $\mathrm{kg}$ crude fat. ${ }^{1}$ Gin trash in the Texas High Plains is composed largely of cotton burrs but also contains immature bolls, stems, leaf material, and other matter.

Limited information is available on the palatibility or acceptability of gin trash by beef cattle. A feeding performance test by Sherrod et. al (1970) indicated that the intake of cotton burr pellets offered free choice to beef steers was only $49.5 \%$ that of alfalfa pellets offered free choice. Thompson and co-workers (1976) reported that ground cotton burrs, whole burrs, and cotton seed hulls have comparable acceptability. In the case of some feedlot users, molasses is mixed with gin trash to increase acceptability and also furnish additional energy in rations.

Nutrient composition data and alternative market prices assumed for different supplemental feeds compared in this study are given in Table 1. It was assumed that $1.5 \mathrm{~kg}$ of gin trash would be wasted for each $\mathrm{kg}$ consumed by range cattle, when fed in bulk form. With pelleted gin trash, there should be near $100 \%$ feeding efficiency. ${ }^{2}$ Use of urea for supplemental protein was restricted to a maximum of $10 \%$ of total protein intake in the study to prevent toxicity problems. Other restrictions included in the analysis were to eliminate urea as a supplement, and also eliminate silage use, as silage is not available in some ranching areas.

\section{Nutritive Value of Range}

The estimated nutrient composition of rangeland grasses in the Texas Rolling Plains varies over the year (Table 2). Both the digestible protein content and metabolizable energy decline as grasses mature in the fall. For example, digestible protein content of blue grama and buffalograss in winter is only 25 and $64 \%$, respectively, of that in summer.

Nutrient composition data for rangeland in Table 2 were utilized in this study to evaluate the economic returns of using gin trash and other supplcmental feeds identified in Table 1 for a cow-calf operation on a 2023.5-hectare ranch. Only one half of the total available range grass was assumed to be consumed per year to prevent overgrazing of the range. The estimated weighted average utilizable yield obtained with the distribution of range sites assumed in Table 2 was $440 \mathrm{~kg}$ air dry weight per acre or 2.20 million $\mathrm{kg}$ total for a 2023.5 ha ranch.

\section{Nutritive Requirements of Range Cattle}

Each cow-producing unit (CPU) on the 2023.5-ha ranch study site included a mature cow and calf and fractional parts of a replacement heifer and a breeding bull, comprising a total of 1.423 animal units per CPU:3. Estimated nutrient. requirements per cow-producing unit decline during the fall as calves are weaned and marketed (Table 3).

Personal interview with Mr. Keith Hansen, animal nutritionist, Hi-Pro Feeds, Friona, Texas.

- Feeding efficiency in this context refers to the amount of feed consumed relative to the amount available for consumption.

"One $453.6 \mathrm{~kg} \mathrm{cow}$, the caf weaned in seven months at $220 \mathrm{~kg}, 0.04$ of a $680.4 \mathrm{~kg}$ bull and 0.10 of a $229.4 \mathrm{~kg}$ heifer. A $90 \%$ calf crop and a $10 \%$ replacement rate for cows was assumed. 
Table 1. Average nutrient composition and alternative market prices for supplemental feeds in the Texas Rolling Plains.

\begin{tabular}{|c|c|c|c|c|c|c|c|}
\hline \multirow{2}{*}{$\begin{array}{l}\text { Supplemental } \\
\text { feed }\end{array}$} & \multirow[b]{2}{*}{$D P^{a}$} & \multicolumn{3}{|c|}{ Nutrient composition } & \multicolumn{3}{|c|}{ Alternative market prices (\$)/ton) } \\
\hline & & $M E^{b}$ & $C A^{c}$ & $\mathrm{P}^{\mathrm{d}}$ & High & Medium & Low \\
\hline Milo & 0.063 & 2.575 & 0.004 & 0.002 & $\$ 100.00$ & $\$ 80.00$ & $\$ 60.00$ \\
\hline Cottonseed mcal & 0.313 & 2.502 & 0.002 & 0.001 & 210.00 & 145.00 & 80.00 \\
\hline Phosphate rock & 0.000 & 0.000 & 0.330 & 0.180 & 130.00 & 95.00 & 60.00 \\
\hline Molasses & 0.018 & 3.009 & 0.009 & 0.001 & 85.00 & 57.50 & 30.00 \\
\hline Alfalfa pellets & 0.118 & 2.053 & 0.012 & 0.002 & 105.00 & 76.50 & 48.00 \\
\hline Commercial supplement $^{e}$ & 0.139 & 2.381 & 0.012 & 0.011 & 127.00 & 127.00 & 127.00 \\
\hline Silage & 0.019 & 1.012 & 0.001 & 0.001 & 20.00 & 15.00 & 12.00 \\
\hline Alfalfa hay & 0.114 & 1.854 & 0.010 & 0.002 & 70.00 & 54.50 & 30.00 \\
\hline Urea & 2.240 & 0.000 & 0.000 & 0.000 & 200.00 & 200.00 & 200.00 \\
\hline Cotton gin trash & 0.015 & 1.515 & 0.007 & 0.002 & 10.00 & variable & 4.00 \\
\hline
\end{tabular}

${ }_{\mathrm{b}}^{\mathrm{a}}$ DP, Digestible protein in kilograms per kilogram of supplement.

b ME, Metabolizable energy in megacalories per kilogram of supplement.

c $\mathrm{CA}$, Calcium in kilograms per kilogram of supplement.

d $\mathrm{P}$, Phosphorus in kilograms per kilogram of supplement.

e Commercial range ration.

Table 2. Estimated seasonal nutritive composition and vegetative composition of rangeland grasses, Rolling Plains of Texas.

\begin{tabular}{|c|c|c|c|c|c|c|c|c|}
\hline $\begin{array}{l}\text { Seasonal nutritive } \\
\text { composition }\end{array}$ & $\begin{array}{l}\text { Blue } \\
\text { grama }\end{array}$ & $\begin{array}{l}\text { Sideoats } \\
\text { grama }\end{array}$ & $\begin{array}{l}\text { Mesquite } \\
\text { grass }\end{array}$ & Buffalograss & Tobosagrass & $\begin{array}{l}\text { Silver } \\
\text { bluestem }\end{array}$ & $\begin{array}{l}\text { Low quality } \\
\text { grasses }^{a}\end{array}$ & $\begin{array}{l}\text { Other } \\
\text { grass }\end{array}$ \\
\hline Vegetative composition $(\%)^{\mathrm{c}}$ & 35 & 2.5 & 10 & 25 & 5 & 5 & 10 & 7.5 \\
\hline \multicolumn{9}{|l|}{ Spring period: } \\
\hline Digestible protein ${ }^{\mathrm{d}}$ & 5.7 & 5.8 & 4.2 & 5.2 & 5.6 & 6.6 & 0 & 3.0 \\
\hline Metabolizable energy ${ }^{\mathrm{e}}$ & 2.47 & 2.43 & 2.27 & 2.43 & 2.29 & 2.45 & 0 & 2.20 \\
\hline \multicolumn{9}{|l|}{ Summer period: } \\
\hline Digestible protein ${ }^{\mathrm{d}}$ & 4.75 & 3.4 & 3.2 & 2.2 & 3.5 & 3.4 & 0 & 2.0 \\
\hline Metabolizable energy & 2.45 & 2.16 & 2.10 & 1.79 & 2.23 & 2.36 & 0 & 1.76 \\
\hline \multicolumn{9}{|l|}{ Fall period } \\
\hline Digestible protein $^{d}$ & 3.8 & 3.2 & 2.2 & 1.6 & 2.4 & 2.7 & 0 & 1.4 \\
\hline Metabolizable energy ${ }^{\mathrm{e}}$ & 2.20 & 2.32 & 1.92 & 1.81 & 2.20 & 2.40 & 0 & 1.54 \\
\hline \multicolumn{9}{|l|}{ Winter period: } \\
\hline Digestible protein ${ }^{\mathrm{d}}$ & 1.2 & 1.3 & 1.0 & 1.4 & 2.7 & 1.5 & 0 & 1.0 \\
\hline Metabolizable energy & 1.61 & 1.94 & 1.68 & 1.90 & 2.29 & 2.34 & 0 & 1.32 \\
\hline
\end{tabular}

${ }_{b}^{a}$ Palatibility of low quality grasses is extremely low and they may not be grazed if other species are available.

bigestible protein content of other grasses is assumed to be low as these grasses are of secondary choice.

c Reported in USDA-SCS Range Conservation Technicians Guide, Section II-E, Deep Hardland Soils, Area 7.

Units in percent of $90 \%$ dry matter. Source: Maddox (no date).

Units in megacalories per kilogram of forage. Source: Maddox (no date).

Calves were assumed to be born in February and weaned in September. Only replacement heifer calves were assumed to be retained over winter, which reduced nutrient requirements per cow-producing unit in the winter period.

\section{Analysis of Supplemental Feeding Programs}

Benefits from supplemental feeding for range cattle are reported in various studies. Newlson (1971) reported increased gains for beef

Table 3. Seasonal nutritive requirements per cow-producing unit, Rolling Plains of Texas ${ }^{\mathrm{a}}$.

\begin{tabular}{lllll}
\hline $\begin{array}{l}\text { Season of } \\
\text { year }\end{array}$ & $\begin{array}{l}\text { Digestible } \\
\text { protein } \\
(\mathrm{kg} / \mathrm{CPU})^{\mathrm{b}}\end{array}$ & $\begin{array}{l}\text { Metabolizable Calcium } \\
\text { energy } \\
(\text { mcal/CPU })^{\mathrm{b}}\end{array}$ & $\begin{array}{l}\text { Phosphorus } \\
(\mathrm{kg} / \mathrm{CPU})^{\mathrm{c}}\end{array}$ & $\begin{array}{l}\text { requirement } \\
(\mathrm{kg} / \mathrm{CPU})^{\mathrm{c}}\end{array}$ \\
\hline Spring & 53.53 & $1,874.50$ & 2.13 & 1.77 \\
Summer & 68.52 & $2,439.03$ & 2.72 & 2.17 \\
Fall & 58.54 & $2,234.65$ & 2.21 & 1.84 \\
Winter & 31.55 & $1,438.47$ & 1.09 & 1.10 \\
Total & 212.15 & $7,986.65$ & 8.16 & 6.88
\end{tabular}

a $\mathrm{A}$ cow-producing unit is defincd as a $453.6-\mathrm{kg}$ cow, a $220-\mathrm{kg}$ calf, 0.04 of a $680.4-\mathrm{kg}$ bull, and 0.10 of a $299.4 \mathrm{~kg}$-replacement heifer.

${ }^{b}$ Sources are Maddox (no date) for cows and calves, and National Academy of Sciences (1970) for other cattle.

c National Academy of Sciences (1970). calves on winter range with supplemental cottonseed meal, liquid protein supplement, and molasses. Denham (1967) reported increased gains from steers on native short grass with supplemental grain and protein. With $1.81 \mathrm{~kg}$ of sorghum per day, steers consumed onequarter less grass than steers without supplement.

The approach taken in this study was to compare available nutrients from rangeland and additional supplemental feeds with estimated major nutritive requirements of a cow-calf operation on a 2,023.5-ha ranch in the Texas Rolling Plains. Supplemental feeding was used to increase ranch carrying capacity with specified nutrient requirements per cow-producing unit. Returns from supplemental feeding with gin trash relative to other conventional supplemental feeding programs were based on the estimated additional livestock income generated on the 2023.5-ha ranch. It was assumed that no additional labor or equipment costs were required for alternative supplemental feeding programs. Cost data for cow-calf production were derived from available extension budgets. Calf income was based on a price of $\$ 0.99$ per $\mathrm{kg}$ of marketable weight. Only the results for selected supplemental feeding programs are reported in this paper.

\section{Returns from Supplemental Feeding}

The estimated net income obtained per cow-producing unit, excluding costs of rangeland use and supplemental feed, was $\$ 116.26$. This estimate incorporated an average marketable calf 
weight of $176 \mathrm{~kg}$ per cow-producing unit, income from cull cow sales, average cash expenses of $\$ 46.60$ per cow-producing unit, and average overhead expenses of $\$ 41.62$ per cow-producing unit. Rangeland cost per cow-producing unit varied with changes in carrying capacity. Rangeland use was priced at $\$ 7.41$ per ha per year, or $\$ 6.19$ per ton of annual utilizable yield.

With no supplemental feeding, estimated carrying capacity of the 2023.5-ha ranch was only 254 cow-producing units and net ranch income was $\$ 14,760$. With supplemental feeding, the ranch could potentially carry a much larger number of cowproducing units with a corresponding increase in estimated annual net ranch income (Table 4).

Alternative range cattle feeding programs for the 2023.5-ha ranch with and without use of gin trash are shown in Table 4 for two sets of feed supplement prices. With Price Set 1, the potential annual net ranch income was $\$ 25,000$ with 504 cowproducing units in the gin trash feeding program. Estimated annual net income was $\$ 20,000$ with 428 cow-producing units when gin trash was excluded from the feeding program. All available range grass was assumed to be utilized during the first three periods of the year in the gin trash feeding program and a combination of gin trash and alfalfa hay was fed in winter. Consumption per cow-producing unit amounted to 2 tons of gin trash and 0.2 tons alfalfa hay in winter. In the alternative feeding program without gin trash, the range was utilized in all periods with some supplementation of alfalfa hay in winter. Cottonseed meal was used to supplement range grass in summer, and some alfalfa hay was used in the fall in both feeding programs.

Silage and urea were considered as additional supplemental feeds available with Price Set 2 . Potential annual net ranch income was $\$ 37,000$ with 662 cow-producing units in the gin trash feeding program under Price Set 2 conditions (Table 4). Estimated annual net income was $\$ 28$ thousand with 454 cowproducing units in the alternative feeding program without gin trash. With Price Set 2 conditions, all available range grass was utilized during the first three periods in both feeding programs. In both programs, the range grass was supplemented with urea in spring, with alfalfa hay in summer, and alfalfa hay in fall. Gin trash was used in both fall and winter in the gin trash feeding program along with some hay and urea. A combination of silage, hay, and urea was used during the winter period in the alternative feeding program.

A price of $\$ 7.00$ per ton for all gin trash used was assumed in both price sets for supplemental feeds (Table 4). A feeding loss of $1.5 \mathrm{~kg}$ of gin trash for each $\mathrm{kg}$ consumed was assumed in the analysis. With $100 \%$ feeding efficiency, up to $\$ 17.50$ could be paid per ton for gin trash. Other results obtained in the study with different combinations of feed supplement prices indicated that $\$ 9.50$ per ton was the upper price limit for gin trash, which is equivalent to $\$ 23.75$ per ton with 100 percent feeding efficiency for gin trash.

Results obtained in this study were for a specific ranch situation with range grass production assumed in Table 2 , with prices of supplemental feeds reported in Table 1, with assumed nutrient requirements per cow-producing unit defined in Table 3 , an assumed rangeland use cost of $\$ 7.41$ per ha, and a price of $\$ 0.99$ per $\mathrm{kg}$ for calves marketed. Changes in these assumed conditions would affect the value of supplemental feeding, including use of gin trash as a supplemental feed. The estimates of potential ranch income and carrying capacity apply only to this assumed ranch situation. The results may differ for other ranch situations. Results also need to be verified with actual

Table 4. Selected supplemental feeding programs for a 2023.5-hectare ranch in the Texas Rolling Plains with and without use of gin trash as a primary supplement.

\begin{tabular}{|c|c|c|c|c|}
\hline \multirow{2}{*}{$\begin{array}{l}\text { Seasonal use of } \\
\text { range and supplement }\end{array}$} & \multicolumn{2}{|c|}{ Feed price set $1^{a}$} & \multicolumn{2}{|c|}{ Feed price set $2^{b}$} \\
\hline & With $\operatorname{trash}^{\mathrm{c}}$ & Without trash ${ }^{d}$ & With $\operatorname{trash}^{\mathrm{e}}$ & Without trash \\
\hline \multicolumn{5}{|l|}{ Spring: } \\
\hline $\begin{array}{l}\text { Rock phosphate }(1,000 \mathrm{~kg}) \\
\text { Range Grass }(1,000 \mathrm{~kg}) \\
\text { Urea }(1,000 \mathrm{~kg})\end{array}$ & $\begin{array}{c}0.45 \\
576.9 \\
n / a\end{array}$ & $\begin{array}{c}0.41 \\
489.69 \\
n / a\end{array}$ & $\begin{array}{r}1.04 \\
700.62 \\
1.18\end{array}$ & $\begin{array}{r}0.73 \\
480.63 \\
0.82\end{array}$ \\
\hline \multicolumn{5}{|l|}{ Summer: } \\
\hline $\begin{array}{l}\text { Range grass }(1,000 \mathrm{~kg}) \\
\text { Alfalfa hay }(1,000 \mathrm{~kg}) \\
\text { Cottonseed meal }(1,000 \mathrm{~kg}) \\
\text { Urea }(1,000 \mathrm{~kg})\end{array}$ & $\begin{array}{c}758.68 \\
-0 \\
35.11 \\
\mathrm{n} / \mathrm{a}\end{array}$ & $\begin{array}{c}643.10 \\
-0- \\
29.80 \\
\text { n/a }\end{array}$ & $\begin{array}{c}884.42 \\
116.66 \\
-0 \\
2.04\end{array}$ & $\begin{array}{l}900.88 \\
-0- \\
-0- \\
1.40\end{array}$ \\
\hline \multicolumn{5}{|l|}{ Fall: } \\
\hline $\begin{array}{l}\text { Rock phosphate } \\
\text { Gin trash consumed }(1,000 \mathrm{~kg}) \\
\text { Range grass }(1,000 \mathrm{~kg}) \\
\text { Alfalfa hay }(1,000 \mathrm{~kg}) \\
\text { Urea }(1,000 \mathrm{~kg})\end{array}$ & $\begin{array}{c}0.49 \\
-0- \\
865.27 \\
70.58 \\
\mathrm{n} / \mathrm{a}\end{array}$ & $\begin{array}{c}0.41 \\
\mathrm{n} / \mathrm{a} \\
734.41 \\
59.92 \\
\mathrm{n} / \mathrm{a}\end{array}$ & $\begin{array}{r}-0- \\
1,575.41 \\
614.94 \\
1.04 \\
1.72\end{array}$ & $\begin{array}{r}0.64 \\
n / a \\
818.46 \\
31.89 \\
1.18\end{array}$ \\
\hline \multicolumn{5}{|l|}{ Winter: } \\
\hline $\begin{array}{l}\text { Gin trash consumed }(1,000 \mathrm{~kg}) \\
\text { Range grass }(1,000 \mathrm{~kg}) \\
\text { Silage }(1,000 \mathrm{~kg}) \\
\text { Alfalfa hay }(1,000 \mathrm{~kg}) \\
\text { Urea }(1,000 \mathrm{~kg})\end{array}$ & $\begin{array}{c}918.66 \\
-0 \\
\text { n/a } \\
90.99 \\
\text { n/a }\end{array}$ & $\begin{array}{c}n / a \\
332.76 \\
n / a \\
122.61 \\
n / a\end{array}$ & $\begin{array}{c}1.572 .02 \\
-0- \\
-0- \\
-0- \\
0.64\end{array}$ & $\begin{array}{r}\mathrm{n} / \mathrm{a} \\
-0- \\
627.95 \\
9.62 \\
0.64\end{array}$ \\
\hline
\end{tabular}


feeding program experiments to evaluate performance of range cattle on gin trash rations.

\section{Summary and Conclusions}

Implications of this analysis are that supplemental feeding may be used to increase ranch carrying capacity and expand income potential. The problem of selecting a profitable supplemental feeding program for range cattle is comparable to other ration formulation problems, i.e., availability and costs of alternative feed inputs must be compared with nutrient requirements of cattle to determine which feeding program will produce the best returns to a ranch operation. One particular problem in ranch applications is that rangeland production is highly variable due to changing weather conditions, and the nutrient composition of range grass is also subject to seasonal change.

The approach taken in this study was to determine the average species composition and seasonal nutrient composition of rangeland grasses on a representative 2023.5-ha ranch in the Rolling Plains. Only one half of the available range grass was assumed to be used in each year to prevent overuse of the range resource. Returns to the ranch operation were based on an assumed market price of $\$ 0.99$ per $\mathrm{kg}$ for calves. Use of altcrnative supplemental feeds at varying prices was evaluated to determine the impact on ranch carrying capacity and potential income, with particular reference to gin trash as a range supplement.

Effects of alternative supplemental feeding programs on the ranch operation varied with the price levels assumed for supplemental feeds. With no supplemental feeding, the 5000acre ranch produced a $\$ 17,760$ annual net income with a carrying capacity of 254 cow-producing units. Some selected results reported in this paper indicated that the ranch could potentially produce $\$ 37,000$ annual net income with a carrying capacity of 662 cow-producing units if intensive supplemental feeding programs were employed. Cotton gin trash was determined to be a valuable supplemental feed for range cattle and was utilized extensively in programs at a price level of $\$ 7.00 \mathrm{per}$ ton. If feeding efficiency was 100 percent rather than 40 percent, a price of $\$ 17.50$ could be paid for gin trash without changing the analysis. Nutrient requirements for digestible protein, metabolizable energy, calcium, and phosphorus were considered in the supplemental feeding programs. Some additional supplementation for other nutrient requirements may be required with a heavy concentration of gin trash in rations. The results of this analysis should be verified with actual feeding trials to evaluate performance of range cattle on feeding programs containing a high percentage of gin trash.

\section{Literature Cited}

Denham, A.H., F.C. Daugherty, and B.E. Dahl, 1967. Grain and protein supplementation of short grass summer range, 1965-1966 Progress Report. Eastern Colorado Range Stat. Akron.

Maddox, L.A., Jr., No. Date. Nutrient requirements of the cow and calf, B-1044, Texas Agr. Ext. Serv. Texas A\&M Univ. College Station.

National Academy of Sciences, 1970, Nutrient requirements of beef cattle, No. 4, Nat. Acad. of Sci., Washington, D.C.

Newlson, A.B., A.L. Newmann, C.H. Herbel, C.C. Yarbrough, E.E. Parker, and J. Whittenburg. 1971. Liquid and dry supplements for wintering range beef calves. Agr. Exp. Sta. Res. Rep. 214, New Mex. State Univ. Las Cruces.

Thompson, Leif H., 1976, Confinement management of beef cow fed various roughage sources. Progress Rep. Texas Tech Univ.

Sherrod, L.B., K.R. Hansen, R.D. Furr, and C.E. DeBord. 1970. Nutritive value of alfalfa and cotton burr pellets. Proc., West. Sec., Amer. Soc. Anim. Sci. 21: 177-182.

U.S. Department of Agriculture, 1967. Range conservation technicians guide, Soil Conserv. Serv. Temple, Texas. 